\title{
Novel 13X Zeolite/PANI electrocatalyst for hydrogen and oxygen evolution reaction
}

\author{
Q4 Rajangam Vinodh ${ }^{a, 1}$, Chinnadurai Deviprasath ${ }^{a, 1}$, \\ Chandu V.V. Muralee Gopi ${ }^{b}$, Venkata Guru Raghavendra Kummara ${ }^{a}$, \\ $\mathrm{Q}_{\mathrm{Q} 2}$ Raji Atchudan ${ }^{\mathrm{c}, 1}$, Tansir Ahamad ${ }^{\mathrm{d}}$, Hee-Je Kim ${ }^{a}$, Moonsuk Yi ${ }^{a, "}$ \\ a School of Electrical and Computer Engineering, Pusan National University, Geumjeong-gu, Busan, 46241, Republic \\ of Korea \\ ${ }^{\mathrm{b}}$ Photonics Laboratory, Division of Computer, Electrical and Mathematical Sciences and Engineering, King Abdullah \\ University of Science and Technology (KAUST), Thuwal Jeddah 23955-6900, Saudi Arabia \\ c School of Chemical Engineering, Yeungnam University, Gyeongsan 36541, Republic of Korea \\ d Department of Chemistry, College of Science, King Saud University, P.O. Box 2455, Riyadh 11451, Saudi Arabia
}

\section{H I G H L I G H T S}

- 13X zeolite were prepared by hydrothermal method.

- The surface area of $13 \mathrm{X}$ was found to be $625 \mathrm{~m} 2 \mathrm{~g}-1$ by BET technique.

- Composite electrode (13X/PANI) was fabricated by electropolymerization technique.

- Tafel slope of HER was found to be $282 \mathrm{mV}$ dec-1 13X/PANI composite.
A R T I C L E I N F O
Article history:
Received 2 May 2020
Received in revised form
30 June 2020
Accepted 22 July 2020
Available online xxx
Keywords:
Zeolite
Polyaniline
Electrochemistry
Composite electrode
Water splitting

* Corresponding author.
E-mail address: msyi@pusan.ac.kr (M. Yi)
https://doi.org/10.1016/j.ijhydene.2020.07.194

A R T I C L E I N F O
Article history:
Received 2 May 2020
Received in revised form
30 June 2020
Accepted 22 July 2020
Available online xxx
Keywords:
Zeolite
Polyaniline
Electrochemistry
Composite electrode
Water splitting

* Corresponding author.
$\quad$ E-mail address: msyi@pusan.ac.kr (M. Yi).
https://doi.org/10.1016/j.ijhydene.2020.07.194

A R T I C L E I N F O
Article history:
Received 2 May 2020
Received in revised form
30 June 2020
Accepted 22 July 2020
Available online xxx
Keywords:
Zeolite
Polyaniline
Electrochemistry
Composite electrode
Water splitting

* Corresponding author.
$\quad$ E-mail address: msyi@pusan.ac.kr (M. Yi).
https://doi.org/10.1016/j.ijhydene.2020.07.194

A R T I C L E I N F O
Article history:
Received 2 May 2020
Received in revised form
30 June 2020
Accepted 22 July 2020
Available online xxx
Keywords:
Zeolite
Polyaniline
Electrochemistry
Composite electrode
Water splitting

* Corresponding author.
$\quad$ E-mail address: msyi@pusan.ac.kr (M. Yi).
https://doi.org/10.1016/j.ijhydene.2020.07.194

A R T I C L E I N F O
Article history:
Received 2 May 2020
Received in revised form
30 June 2020
Accepted 22 July 2020
Available online xxx
Keywords:
Zeolite
Polyaniline
Electrochemistry
Composite electrode
Water splitting

* Corresponding author.
$\quad$ E-mail address: msyi@pusan.ac.kr (M. Yi).
https://doi.org/10.1016/j.ijhydene.2020.07.194

A R T I C L E I N F O
Article history:
Received 2 May 2020
Received in revised form
30 June 2020
Accepted 22 July 2020
Available online xxx
Keywords:
Zeolite
Polyaniline
Electrochemistry
Composite electrode
Water splitting

* Corresponding author.
$\quad$ E-mail address: msyi@pusan.ac.kr (M. Yi).
https://doi.org/10.1016/j.ijhydene.2020.07.194

A R T I C L E I N F O
Article history:
Received 2 May 2020
Received in revised form
30 June 2020
Accepted 22 July 2020
Available online xxx
Keywords:
Zeolite
Polyaniline
Electrochemistry
Composite electrode
Water splitting

* Corresponding author.
$\quad$ E-mail address: msyi@pusan.ac.kr (M. Yi).
https://doi.org/10.1016/j.ijhydene.2020.07.194

A R T I C L E I N F O
Article history:
Received 2 May 2020
Received in revised form
30 June 2020
Accepted 22 July 2020
Available online xxx
Keywords:
Zeolite
Polyaniline
Electrochemistry
Composite electrode
Water splitting

* Corresponding author.
$\quad$ E-mail address: msyi@pusan.ac.kr (M. Yi).
https://doi.org/10.1016/j.ijhydene.2020.07.194

A R T I C L E I N F O
Article history:
Received 2 May 2020
Received in revised form
30 June 2020
Accepted 22 July 2020
Available online xxx
Keywords:
Zeolite
Polyaniline
Electrochemistry
Composite electrode
Water splitting

* Corresponding author.
$\quad$ E-mail address: msyi@pusan.ac.kr (M. Yi).
https://doi.org/10.1016/j.ijhydene.2020.07.194

A R T I C L E I N F O
Article history:
Received 2 May 2020
Received in revised form
30 June 2020
Accepted 22 July 2020
Available online xxx
Keywords:
Zeolite
Polyaniline
Electrochemistry
Composite electrode
Water splitting

* Corresponding author.
$\quad$ E-mail address: msyi@pusan.ac.kr (M. Yi).
https://doi.org/10.1016/j.ijhydene.2020.07.194

A R T I C L E I N F O
Article history:
Received 2 May 2020
Received in revised form
30 June 2020
Accepted 22 July 2020
Available online xxx
Keywords:
Zeolite
Polyaniline
Electrochemistry
Composite electrode
Water splitting

* Corresponding author.
$\quad$ E-mail address: msyi@pusan.ac.kr (M. Yi).
https://doi.org/10.1016/j.ijhydene.2020.07.194

A R T I C L E I N F O
Article history:
Received 2 May 2020
Received in revised form
30 June 2020
Accepted 22 July 2020
Available online xxx
Keywords:
Zeolite
Polyaniline
Electrochemistry
Composite electrode
Water splitting

* Corresponding author.
$\quad$ E-mail address: msyi@pusan.ac.kr (M. Yi).
https://doi.org/10.1016/j.ijhydene.2020.07.194

A R T I C L E I N F O
Article history:
Received 2 May 2020
Received in revised form
30 June 2020
Accepted 22 July 2020
Available online xxx
Keywords:
Zeolite
Polyaniline
Electrochemistry
Composite electrode
Water splitting

* Corresponding author.
$\quad$ E-mail address: msyi@pusan.ac.kr (M. Yi).
https://doi.org/10.1016/j.ijhydene.2020.07.194

\section{G R A P H I C A L A B S T R A C T}

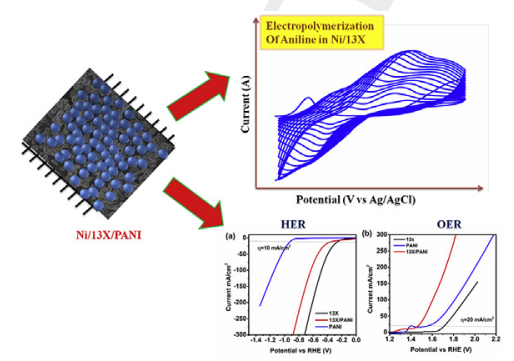

A B S T R A C T

In this work, first $13 \mathrm{X}$ zeolite was prepared by the hydrothermal method. Then, the composite electrode was fabricated by using $13 \mathrm{X}$ zeolite and aniline monomer in nickel foam by electropolymerization technique in an acidic medium (13X/PANI). The synthesized 13X zeolite was characterized by physicochemical characterization techniques such as Fourier transform infra-red (FT-IR) spectroscopy, X-ray photoelectron spectroscopy (XPS), field emission scanning electron microscopy (FE-SEM), high-resolution transmission electron microscopy (HR-TEM), X-ray diffraction (XRD) pattern and nitrogen sorption isotherm. 13X/ PANI composite was further analyzed by XRD, XPS and FE-SEM techniques. Furthermore, the catalyst activity of the synthesized 13X, PANI and 13X/PANI composite electrodes was evaluated in hydrogen evolution reaction (HER) and oxygen evolution reaction (OER) by using linear square voltammetry (LSV) and Tafel slope method. The Tafel slopes of HER were found to be $203 \mathrm{mV} \mathrm{dec}-1,440 \mathrm{mV} \mathrm{dec}^{-1}$ and $282 \mathrm{mV} \mathrm{dec}^{-1}$ for $13 \mathrm{X}$, PANI and 13X/ PANI-15 electrodes respectively. While the OER Tafel slopes were found to be $423 \mathrm{mV} \mathrm{dec}^{-1}$,

0360-3199/@ 2020 Hydrogen Energy Publications LLC. Published by Elsevier Ltd. All rights reserved. 
$310 \mathrm{mV} \mathrm{dec}^{-1}$ and $168 \mathrm{mV} \mathrm{dec}^{-1}$ for 13X, PANI and 13X/PANI-15, respectively. 13X/PANI-15 electrodes show excellent catalytic performance about the overpotential at $10 \mathrm{~mA} \mathrm{~cm}^{-2}$ for HER and the overpotential at $20 \mathrm{~mA} \mathrm{~cm}^{-2}$ for OER. The obtained results suggest fabricated novel electrodes are a potential candidate for HER and OER reaction and can be open new avenue for other electrochemical reactions.

๑ 2020 Hydrogen Energy Publications LLC. Published by Elsevier Ltd. All rights reserved.

\section{Introduction}

Depletion of fossil fuels and increased pollution, the cost of fuels and inadequate environmental problems have emerged the search for alternative clean and energy resources [1,2]. Among the gases, hydrogen is considered as the cleanest and most sustainable energy pathway for converting traditional fossil fuels. One of the main objectives of a successful hydrogen economy is to produce hydrogen gas at a low cost [3-5]. Intermittent renewable energy resources, such as solar energy, wind and wind power, generate environmentally friendly hydrogen by electrochemical water splitting. The total water splitting is the combination of HER and OER. To reduce their large overpotentials, both HER and OER require very active electrocatalyst desperately [6-11]. Furthermore, to understand continuous water splitting for commercial applications, the reaction must be carried out on the same alkaline electrolyte. Hence, developing active and effective electrocatalyst to separate water as a whole under the same electrolyte, and reducing costs, is very attractive to large-scale hydrogen production. Nowadays, noble metals and its derivatives $\left(\mathrm{Pt} / \mathrm{C}, \mathrm{IrO}_{2}\right.$ and $\mathrm{RuO}_{2}$ ) have exhibited unique electrocatalytic efficiency for both HER and OER performances but the expensive cost and inadequate resources harshly hinder their widespread use [12-14].

Conductive polymers (CPs) have been considered as one of the efficient supporting resources for solar cell and fuel cell applications. Among the different CPs, polyaniline (also called as PANI) is one of the excellent materials due to its outstanding physicochemical properties such as simple synthesis, stable at chemical and environmental conditions, good conductivity, high surface area, small pore volume and requirement of a cheap precursor. Therefore, potential uses of conducting polymers include organic light-emitting diodes (OLED) [15,16], transistors [17,18], solar cells [19,20], pHsensors [21], biosensors [22], rechargeable batteries, membranes [23], electrochromic displays [24], corrosion protection coating [25], fuel cells [26-29] and supercapacitors [30].

It is best to incorporate the polymer network into organic hosts because it helps to combine characteristics of the parent component as a result of their molecular level interactions. 13X zeolites are regarded as one of the finest host materials because of their extremely well-ordered/regular interconnected structures and negatively charged-uniform surface with cages of various dimensions and structures and interchangeable cations. Besides, the incorporation of CPs into zeolites, the high conductivity of the CPs protects zeolite materials from degradation and reduces its aging rate.
Therefore, the $13 \mathrm{X}$ zeolite could be improved after the incorporation of conducting polymer, PANI. PANI is often employed as an electrocatalyst support material for many electrochemical applications which includes electrochemical energy storage devices (fuel cells, supercapacitors and batteries) because of its excellent properties like the ease of preparation, good conductivity, low-cost monomer and excellent stability [31]. Therefore, the synthesis of $13 \mathrm{X}$ zeolite and PANI could resolve defects present in the electrode materials and improve HER and OER performance.

No articles have yet been published on the performance of HER and OER using 13X zeolite/PANI composites to the best of the author's knowledge. Taking consideration of the above ideas, herein we report a facile synthetic method to construct novel 13X@PANI microspheres grown directly on nickel (Ni) foam substrates by the electrochemical polymerization of aniline, and their electrocatalytic effect has been studied.

\section{Experimental}

\section{Materials}

The monomer, aniline $\left(\mathrm{C}_{6} \mathrm{H}_{5} \mathrm{NH}_{2}\right)$ was procured from Daejung Chemicals, South Korea. It was distilled in each experiment prior to use. The chemicals used for $13 \mathrm{X}$ zeolite syntheses such as sodium aluminate $\left(\mathrm{NaAlO}_{2}\right)$, sodium hydroxide $(\mathrm{NaOH})$ and sodium silicate $\left(\mathrm{Na}_{2} \mathrm{SiO}_{3}\right)$ were obtained from Sigma Aldrich, USA. The conductive carbon black was purchased from Alfa Aesar, USA. Ni foam, poly (vinylidene fluoride) [PVDF; $-\left(\mathrm{C}_{2} \mathrm{H}_{2} \mathrm{~F}_{2}\right)_{n^{-}}$], potassium hydroxide $(\mathrm{KOH})$ and 1methyl-2-pyrrolidinone (NMP; $\mathrm{C}_{5} \mathrm{H}_{9} \mathrm{O}$ ) were also obtained from Sigma-Aldrich, USA. Conc. $\mathrm{H}_{2} \mathrm{SO}_{4}$ and sodium sulphate were procured from Daejung Chemicals, South Korea. All the experiments were carried out using distilled water. Except aniline monomer, all the other chemicals were used as received.

\section{$13 \mathrm{X}$ zeolite synthesis}

Thermally stable $13 \mathrm{X}$ zeolite sample was prepared using sodium silicate and sodium aluminate as silica-alumina source through the hydrothermal method. A brief synthesis procedure and optimized reaction conditions are as follows: $500 \mathrm{~mL}$ polypropylene (PP) bottle containing sodium aluminate (7.12 g), sodium hydroxide (3.86 g) and deionized water $(80 \mathrm{~mL})$ equipped with magnetic stirrer consisting of Teflon blade and maximum rpm (rotation per minute) of 1000 at ambient temperature. Then, an already prepared sodium silicate 
solution was gently transferred into the above reaction mixture with the use of $2 \mathrm{~mL}$ dropper. The reaction was allowed to continue stirring for another $6 \mathrm{~h}$. Subswequently, the obtained white mixture was incubated for $12 \mathrm{~h}$ at ambient temperature in a completely closed PP bottle to reorganize the reactant for the development of nuclei. Then, it was crystallized for $48 \mathrm{~h}$ at $80^{\circ} \mathrm{C}$ under static condition. In the final process, the PP bottle was cooled by the external tab water and then the vacuum pump along with filtration unit was employed to separate the white solid and the filtrate was washed several times continuously 9 in deionized water until the $\mathrm{pH}$ was low $(\mathrm{pH}>10)$. The final precipitate was desiccated in an oven at $95^{\circ} \mathrm{C}$ for $12 \mathrm{~h}$ and finely crushed.

\section{Fabrication of working electrode}

The fabrication of the working electrode consists of three steps. The detailed experimental procedure was as follows.

(i) Pre-treatment of Ni foam: First, the desired size of Ni foam was cut with the help of scissor (corrosion-free) and then submerged into a concentrated hydrochloric acid solution and then subjected into ultra-sonication for $10 \mathrm{~min}$ to remove the surface oxide layer. To attain super clean Ni foam, it was further treated with deionized water, acetone and $95 \%$ ethanol for $10 \mathrm{~min}$ each in sonication bath. Finally, the pre-treated Ni foam was dried in an oven at moderate temperature $\left(60^{\circ} \mathrm{C}\right)$ for $4 \mathrm{~h}$.

(ii) 13X@Ni foam: The electrode, 13X@Ni foam was fabricated by mixing of $80 \% 13 \mathrm{X}$ zeolite (active material). $10 \%$ carbon black, 10\% PVDF and NMP solution to make a slurry and then coated onto the pre-treated $\mathrm{Ni}$ foam and dried for $12 \mathrm{~h}$ at $60^{\circ} \mathrm{C}$ in an oven. The mass loading was approximately $4 \mathrm{mg} \mathrm{cm}^{-2}$.

(iii) Electrochemical polymerization of aniline@13X-Ni foam: Electrochemical polymerization of aniline $(0.1 \mathrm{M})$ was carried out using Biologic-SP150 electrochemical work station in sulfuric acid solution $(0.5 \mathrm{M})$ with a single compartment three-electrode cell with $13 \mathrm{X}-\mathrm{Ni}$ foam, $\mathrm{Ag} / \mathrm{AgCl}$ and platinum wire were used as working, reference and counter electrode, respectively. PANI, electrochemically synthesized from $0.5 \mathrm{M} \mathrm{H}_{2} \mathrm{SO}_{4}+0.1 \mathrm{M}$ aniline monomer by cycling (10 cycles) the working electrode potential from -0.2 to $1.2 \mathrm{~V}$ vs. Ag/AgCl electrode at sweeping rate of $50 \mathrm{mV} \mathrm{s}^{-1}$. The prepared electrode material was named as 13X/PANI-10. We carried out the same experimental procedure with varying cycle numbers 15,20 and 25 and named the electrode as 13X/PANI-15, 13X/PANI-20 and 13X/PANI25 , respectively. The graphic illustration of the fabricated electrode materials was depicted in Fig. 1.

\section{Physicochemical characterizations}

The structural morphology of the materials was analyzed by FE-SEM (Hitachi, S-2400) and HR-TEM (JEOL). The crystalline nature of the $13 \mathrm{X}$ and 13X/PANI composite was characterized by XRD (Xpert3). Nitrogen sorption isotherm at $77 \mathrm{~K}$ was performed to evaluate BET surface area, pore volume and pore diameter (BELSORB-Max). The oxidation state and elemental composition of the samples were studied by XPS (Axis Supra).

\section{HER and OER performance}

Using Biologic-150 electrochemical workstation all the electrochemical analysis was studied. $\mathrm{Ag} / \mathrm{AgCl}$ and graphite rod were used as the reference and counter electrode, respectively and $1 \mathrm{M} \mathrm{KOH}$ was used as the supporting electrolyte. The Ag/ AgCl electrode potential was set with reversible hydrogen electrode (RHE) potential and rinsed with distilled water prior to use. Nitrogen gas was purged in the solution throughout the experiment to remove dissolved oxygen presented in the electrolyte solution. LSV polarization curves were employed to study the electrochemical performance of the fabricated electrode materials and it was recorded between 1.2 and $2.2 \mathrm{~V}$ for OER and 0.1 and -1.4 for HER at $2 \mathrm{mV} \mathrm{s}^{-1}$. All the data were acquired without iR-correction.

\section{Results and discussions}

\section{X zeolite}

Fig. 2(a) shows the XRD pattern of the prepared 13X zeolite. The diffraction pattern of the prepared material was sharp and crystalline. Further, no other diffraction peaks were observed and also the prepared $13 \mathrm{X}$ zeolite was in good agreement with the standard 13X zeolite (JCPDS card number 38-0237). The standard 13X zeolite material was depicted in the inset of Fig. 2(a). It is clearly illustrating that only one phase of 13X zeolite was successfully formed.

Fig. 2(b) represents the FT-IR spectrum of the $13 \mathrm{X}$ zeolite. The tetrahedral symmetric and asymmetric stretching vibration of $\mathrm{M}-\mathrm{O} 4$ [32] $(\mathrm{M}=\mathrm{Si}$ or $\mathrm{Al})$ was positioned at 982 and $678 \mathrm{~cm}^{-1}$, respectively. The building block of octahedral structures was confirmed by the double six-membered rings centered at $560 \mathrm{~cm}-1[33,34]$. The peak at $459 \mathrm{~cm}^{-1}$ could be allotted to the absorption band of the metal-oxygen bending vibration of the zeolite (metal $=\mathrm{Al}$ or $\mathrm{Si}$ ) $[35,36]$. Furthermore, the peak positioned at $758 \mathrm{~cm}^{-1}$ was attributed to the existence of $\mathrm{Si}(\mathrm{Al})-\mathrm{O}$ vibration peak $[37,38]$. The broad absorption band at $3458 \mathrm{~cm}^{-1}$ occurred due to the presence of physically adsorbed water molecules in the synthesized $13 \mathrm{X}$ zeolite. Fig. 2(c) shows the nitrogen sorption isotherm of $13 \mathrm{X}$ zeolite and pore size distribution curve. $13 \mathrm{X}$ zeolite exhibits type I adsorption-desorption isotherm. The sharp increase in the adsorption at low relative pressure $\left(\mathrm{p} / \mathrm{p}_{0}=0.1\right)$ illustrates that the existence of micropores. The prepared $13 \mathrm{X}$ zeolite exhibited surface area of $625 \mathrm{~m}^{2} \mathrm{~g}^{-1}$ and it is in well coincide with the available literature [39].

Fig. 3(a) and (b) represent the surface morphology of the prepared 13X zeolite and it was studied by FE-SEM. From the results obtained, the $13 \mathrm{X}$ zeolite exhibits octahedral crystalline form and the particle size of the material can be estimated from several micrometers into nanometers. The zeolite crystal formed conglomerates. In addition, the material possesses a high crystallization degree because there is no sign for the detection of amorphous materials in this technique. From the elemental mapping analysis of Fig. 3(c)-(f), the presence of the 


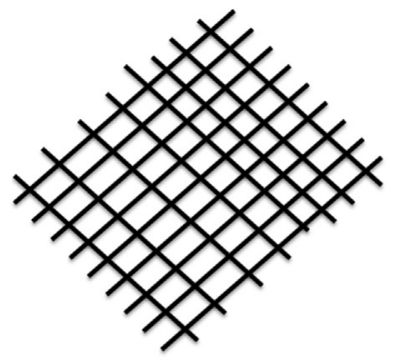

NF

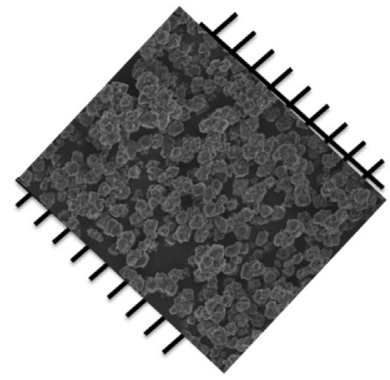

NF/13X

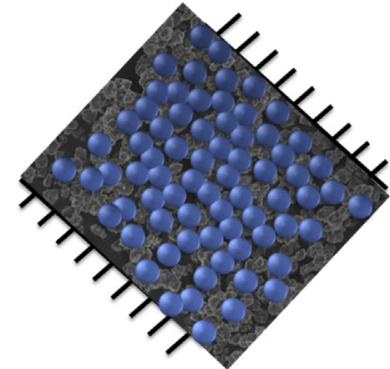

NF/13X/PANI

Fig. 1 - Schematic diagram of the fabricated working electrode.
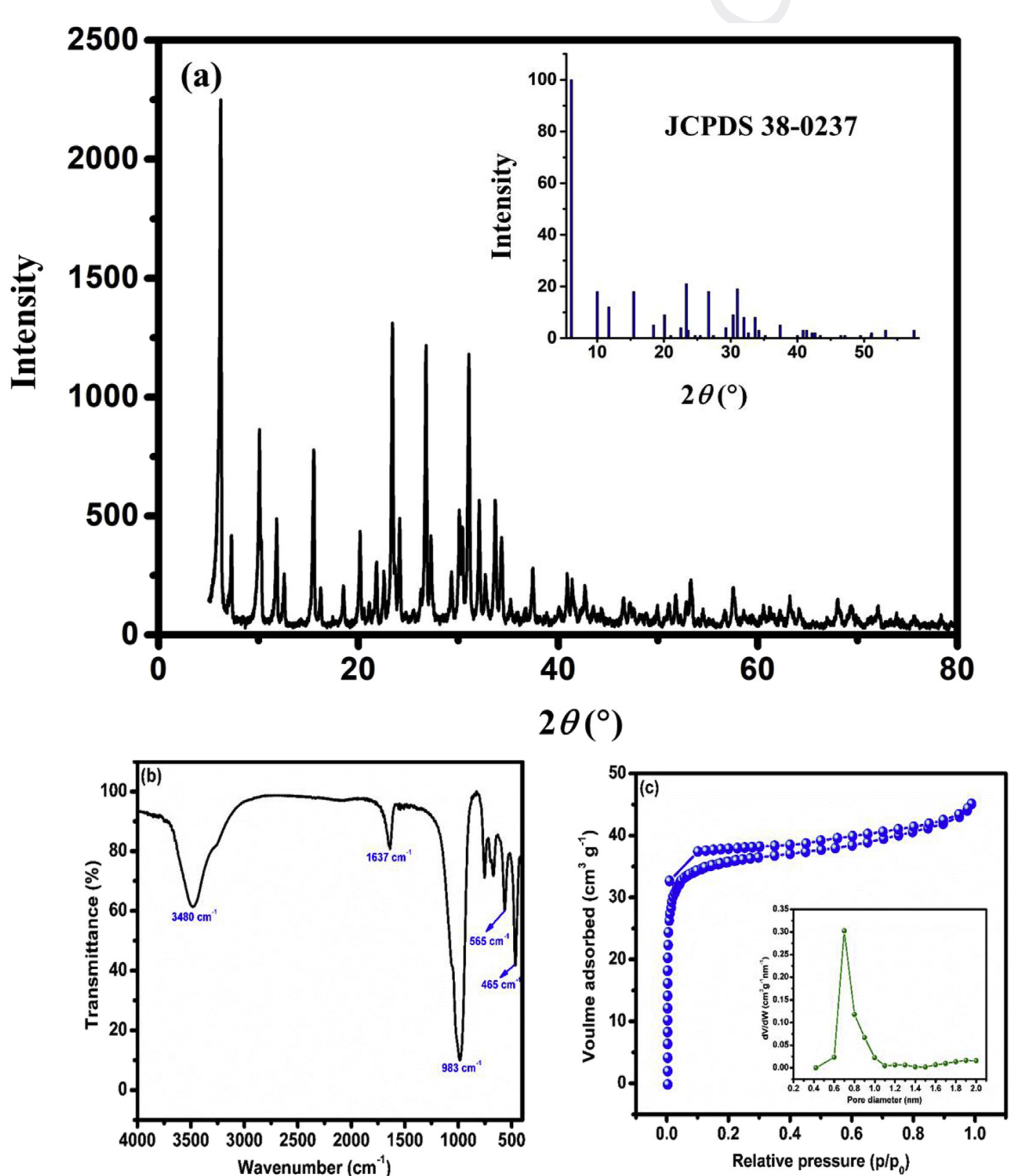

Fig. 2 - (a) XRD pattern (Inset: Standard pattern of JCPDS 38-0237), (b) FTIR and (c) $\mathrm{N}_{2}$ sorption isotherm of $13 \mathrm{X}$ zeolite. Inset of (c): Pore size distribution curve of $13 \mathrm{X}$ zeolite. 

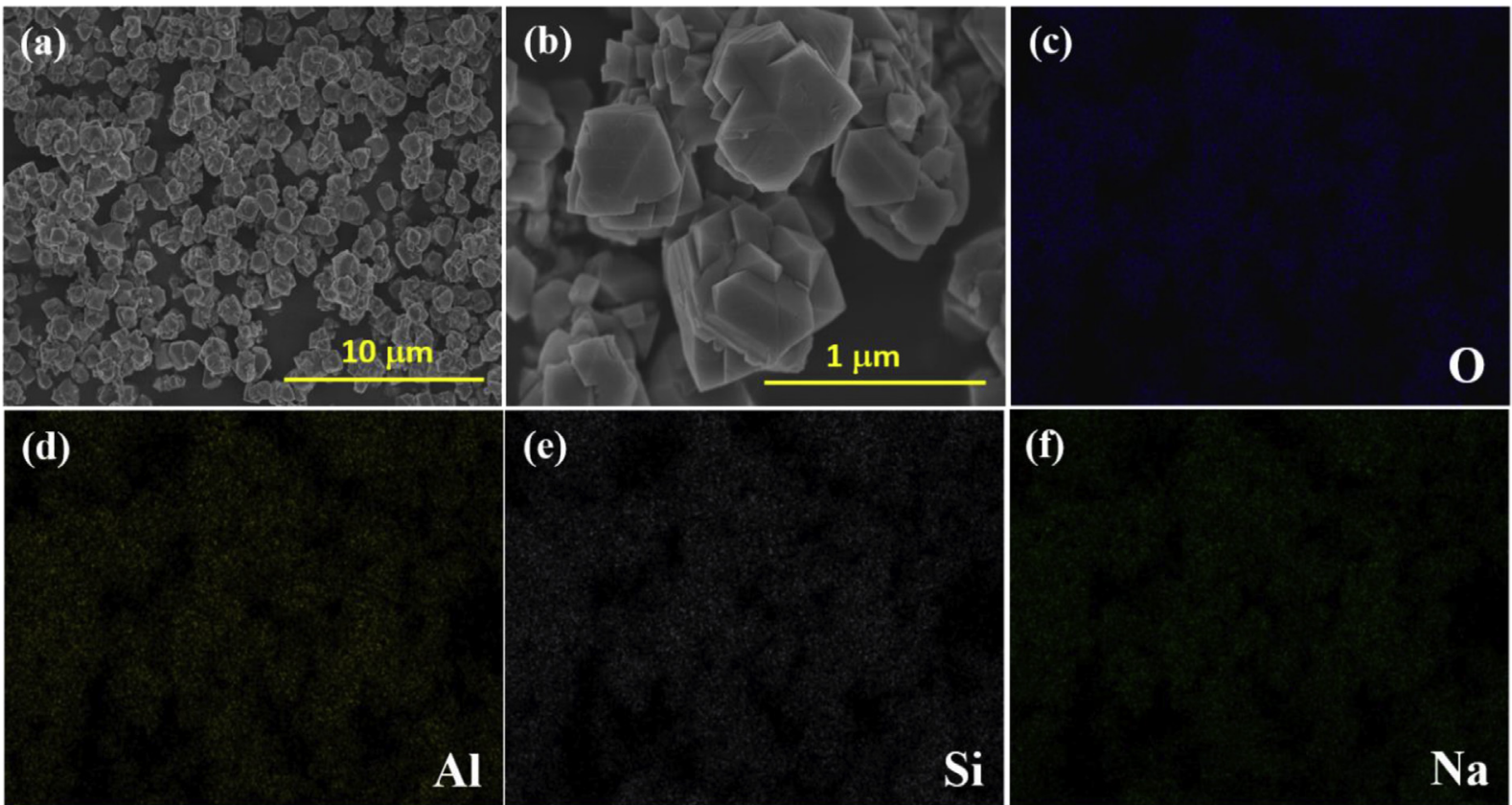

(e)
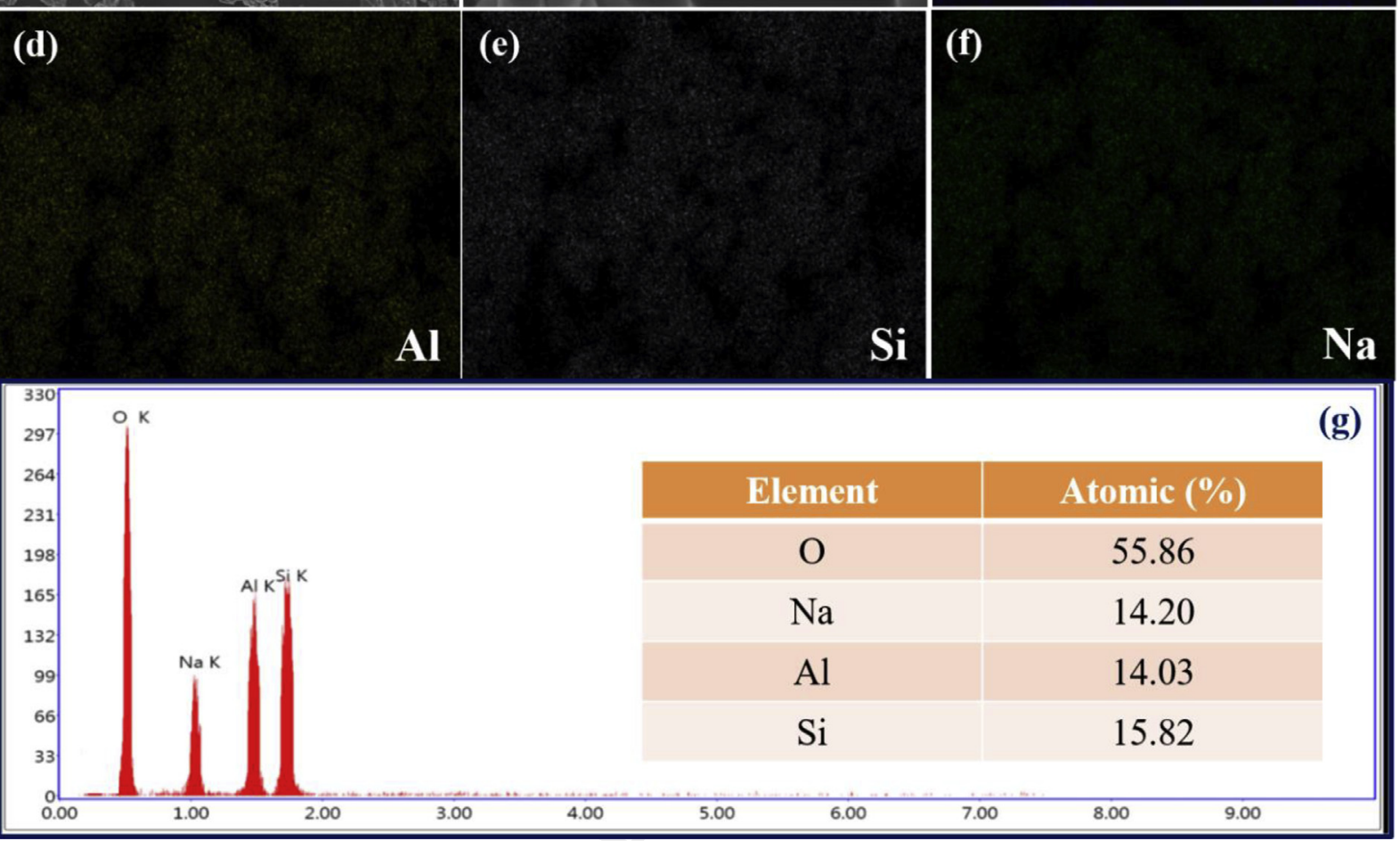

Fig. 3 - SEM images along with elemental mapping analysis of $13 X$ zeolite.

following elements of O (oxygen), $\mathrm{Al}$ (aluminium), Si (silicon) and $\mathrm{Na}$ (sodium) were confirmed in the $13 \mathrm{X}$ zeolite. From the EDAX spectrum (Fig. 3(g)), the key constituents of the 13X zeolite are $\mathrm{O}, \mathrm{Al}, \mathrm{Si}$ and $\mathrm{Na}$. The atomic percentage of $\mathrm{O}, \mathrm{Na}, \mathrm{Al}$ and $\mathrm{Si}$ are $55.18,14.20,14.03$ and 15.82\%, respectively. Subsequently, 13X zeolite was further studied by HR-TEM and it was shown in Fig. 4. It shows that good crystallinity and grows steadily. The high resolution HR-TEM images (Fig. 4(d) and (e)) show lattice fringes with a periodicity that confirms structural alignment. The aligned fringes correspond to the (111) plane of 13X zeolite as was displayed by the XRD peak presenting at $2 \theta=7^{\circ}$ in Fig. 2(a). As shown in Fig. 4(f), the electron diffraction pattern designates the development of body-centered cubic crystals.

\section{Electrochemical polymerization of aniline into $13 \mathrm{X}$ zeolite}

Fig. 4(g) exhibits the electrochemical polymerization of aniline into the $13 \mathrm{X}$ coated nickel foam substrate $(13 \mathrm{X} / \mathrm{Ni}$ foam) by sweeping the potential from -0.2 to $1.2 \mathrm{~V}$ vs. $\mathrm{Ag} / \mathrm{AgCl}$ at sweep rate of $50 \mathrm{mV} \mathrm{s}^{-1}$ in an aqueous solution of $1 \mathrm{mM}$ aniline $+0.5 \mathrm{M} \mathrm{H}_{2} \mathrm{SO}_{4}$ with varying the cycle number 10, 15, 20 and 25 . Towards positive potential that is the potential was increased to $+0.8 \mathrm{~V}$, the aniline monomer gets readily electropolymerized onto the $13 \mathrm{X} / \mathrm{Ni}$ foam with an observed increasing current. The plausible reason for the increasing current is the oxidation of aniline monomers and the initiation of the electropolymerization of PANI in the first cycle $[40,41]$ and the film growth can be established by the current increases with the increasing voltammogram cycle number. The electropolymerization of aniline into nickel foam was depicted in Fig. S1.

\section{Composite electrode, 13X/PANI}

Fig. 5(a) and (b) shows the FE-SEM images of electrochemically synthesized PANI-15 on nickel foam. It shows the existence of nearly tiny bulbous (spherical) particles with uneven dimensions. Whereas FE-SEM images of 13X/PANI-15 composite (Fig. 5(c) and (d)) illustrate the growth of random aggregates of spherical particles with irregular sizes. Such morphology probably caused from the cementation of the PANI moieties with $13 \mathrm{X}$ zeolite particles [42,43].

Fig. 5(e) depicts the XRD patterns of Ni foam, PANI/NF and 13X-PANI/NF. Remarkably, XRD pattern of $13 \mathrm{X}$ zeolite was 

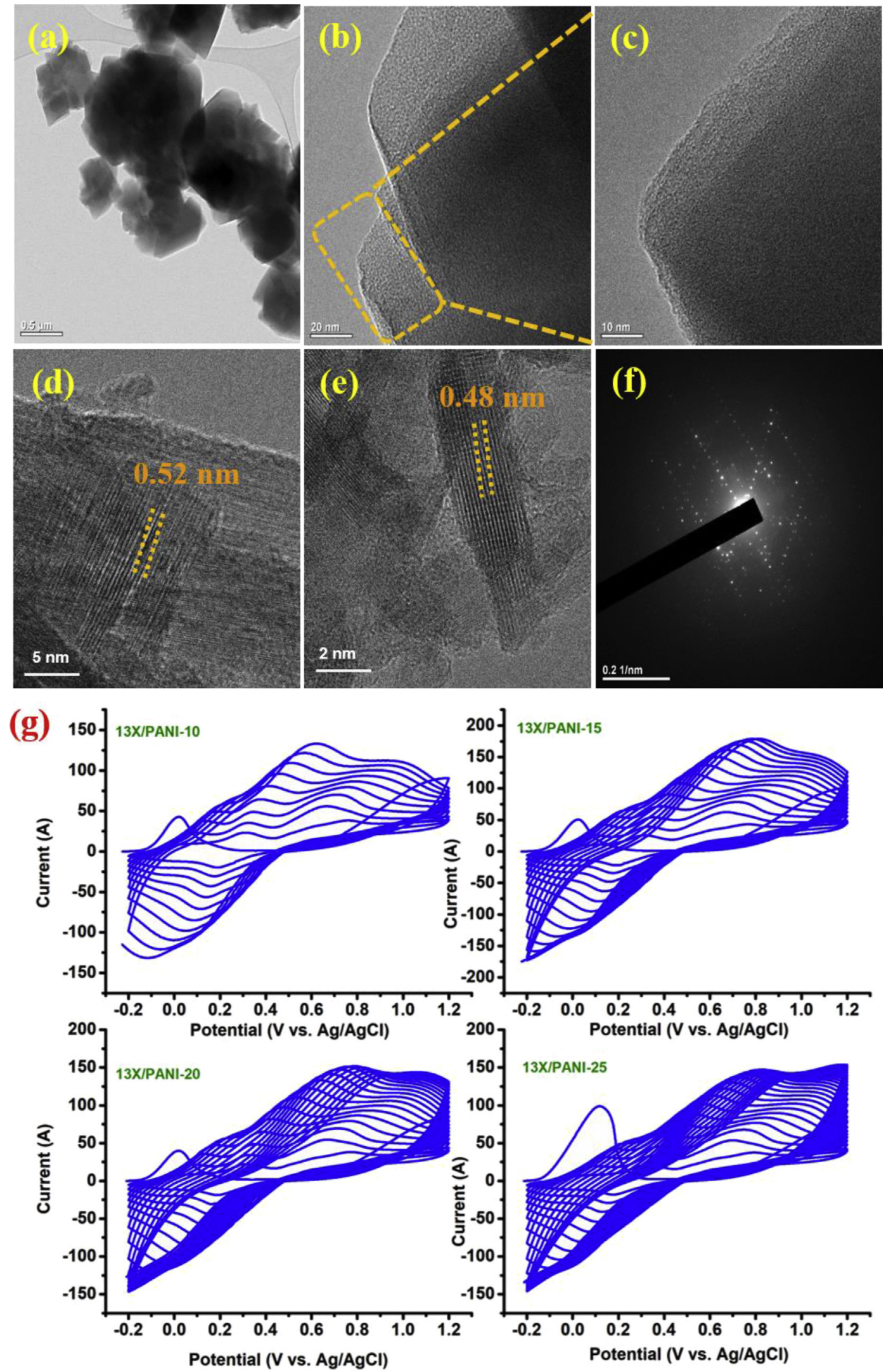

Fig. 4 - (a)-(f) HR-TEM and EDAX images of as-synthesized 13X; (g) The growth of the PANI films onto the 13X/Ni foam electrode with different cycle number. 

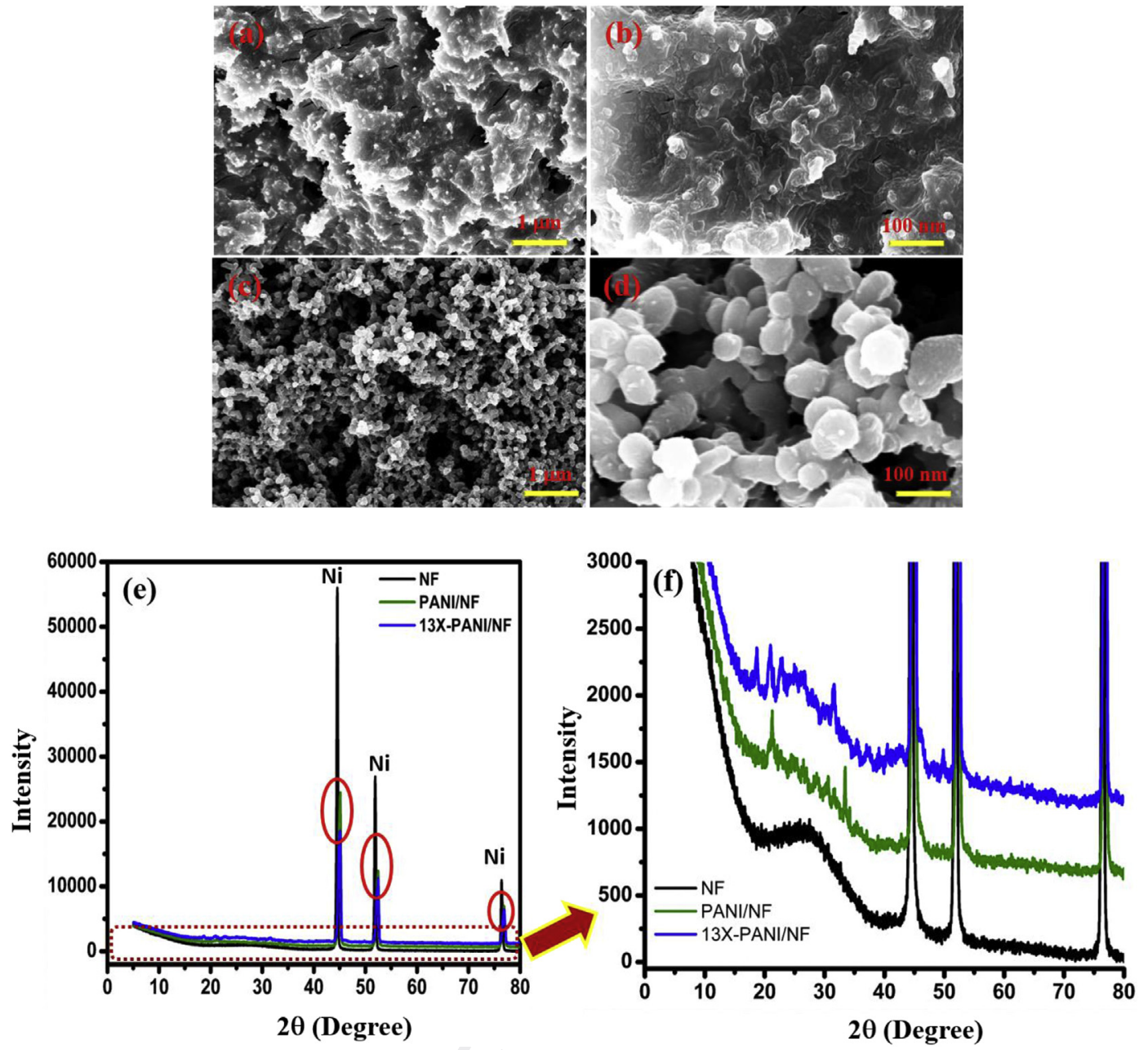

Fig. 5 - (a) and (b) FE-SEM images of PANI-15; (c) and (d) FE-SEM images of 13X/PANI-15; (e) XRD patterns of NF, PANI/NF and 13X-PANI/NF; (f) Expanded view of (e).

significantly altered to a completely amorphous pattern in the 13X/PANI composite during electrochemical polymerization of aniline in the presence of 13X zeolite. Notably, similar XRD patterns were also observed in the case of 13X/PANI composite, suggesting the loss of crystallinity of the $13 \mathrm{X}$ zeolite $3 \mathrm{D}$ network [44]. These results clearly revealed that PANI was successfully electrochemical deposited on the surface of the 13X zeolite.

Fig. 6(a) represents the XPS survey spectra of 13X, PANI and 13X/PANI-15 composite. The XPS survey spectrum of $13 \mathrm{X}$ consists the elements of $\mathrm{Na}, \mathrm{Si}, \mathrm{Al}$ and $\mathrm{O}$. PANI and 13X/PANI15 consisting of the elements of $\mathrm{O}, \mathrm{N}$ and $\mathrm{C}$ and $\mathrm{O}, \mathrm{N}, \mathrm{C}, \mathrm{Na}, \mathrm{Al}$ and $\mathrm{Si}$, respectively. It clearly illustrates that the successful loading of PANI into 13X zeolite. Fig. 6(b) corresponds to the $\mathrm{Na}$ 1s spectra of $13 \mathrm{X}$ and $13 \mathrm{X} / \mathrm{PANI}$. In $13 \mathrm{X}$, the only one broad peak observed at $1072.7 \mathrm{eV}$ which are assigned to the $\mathrm{Na}_{2} \mathrm{O}$. While in 13X/PANI the little shift was noticed due to the interaction with PANI. In 13X, the peak centered at $101 \mathrm{eV}$ assigned to the standard XPS peak of silica. Further, it was deconvoluted into two peaks at 101.7 and $103.1 \mathrm{eV}$ was assigned $\mathrm{Ss}_{2}$ and silicates, respectively (Fig. 6(c)). 13X/PANI shows little shift in their binding energy due to the interaction of PANI with 13X. In $13 \mathrm{X}$, the deconvoluted $\mathrm{Al} 2 \mathrm{p}$ spectrum displays the Al-O band of $\mathrm{Al}_{2} \mathrm{O}_{3}$ at $74.7 \mathrm{eV}$ (Fig. $6(\mathrm{~d})$ ). Nevertheless, new peaks presented at 75.2 and $73.7 \mathrm{eV}$ which are allotted to $\mathrm{AlO}$ of $\mathrm{Al}(\mathrm{OH})_{3}$ and $\mathrm{AlO}_{2}$. However, in the case of 13X/PANI the peaks intensity was decreased, and new peaks are formed at $69.1 \mathrm{eV}$ illustrating the aluminium interaction with $\mathrm{N}$ species of PANI. The high-resolution $C$ 1s spectrum is given Fig. 6(e). It deconvoluted into four peaks, such as $\mathrm{C}-\mathrm{C}, \mathrm{O}-\mathrm{C}-\mathrm{O}, \mathrm{C}=\mathrm{O}$ and $\mathrm{O}-\mathrm{C}=\mathrm{O}$ at binding energies of 284.1, 285.3, 286.4 and 289.1, respectively. The $\mathrm{O}$ 1s spectrum (Fig. 6(f)) deconvoluted into three peaks at 530.3, 531.8 and $534.4 \mathrm{eV}$ assigned to $\mathrm{C}=\mathrm{O}, \mathrm{C}-\mathrm{O}$ and $\mathrm{O}-\mathrm{C}=\mathrm{O}$, respectively [45]. The successful deposition of PANI was confirmed through the N 1s core-level spectra of PANI and 13X/ PANI. PANI showed an almost symmetric $\mathrm{N} 1 \mathrm{~s}$ line centered at $399 \mathrm{eV}$ (Fig. 6(g)). This N 1s core spectrum has two peaks with an equivalent intensity of $398.3 \mathrm{eV}$ and $399.5 \mathrm{eV}$. They belong to chemically different nitrogen species in the imine $(=\mathrm{N}-)$ and amine (-NH-) fractions of the emeraldine base [46]. While in the case of 13X/PANI the peak intensity of imine and amine type nitrogen decreases significantly. 


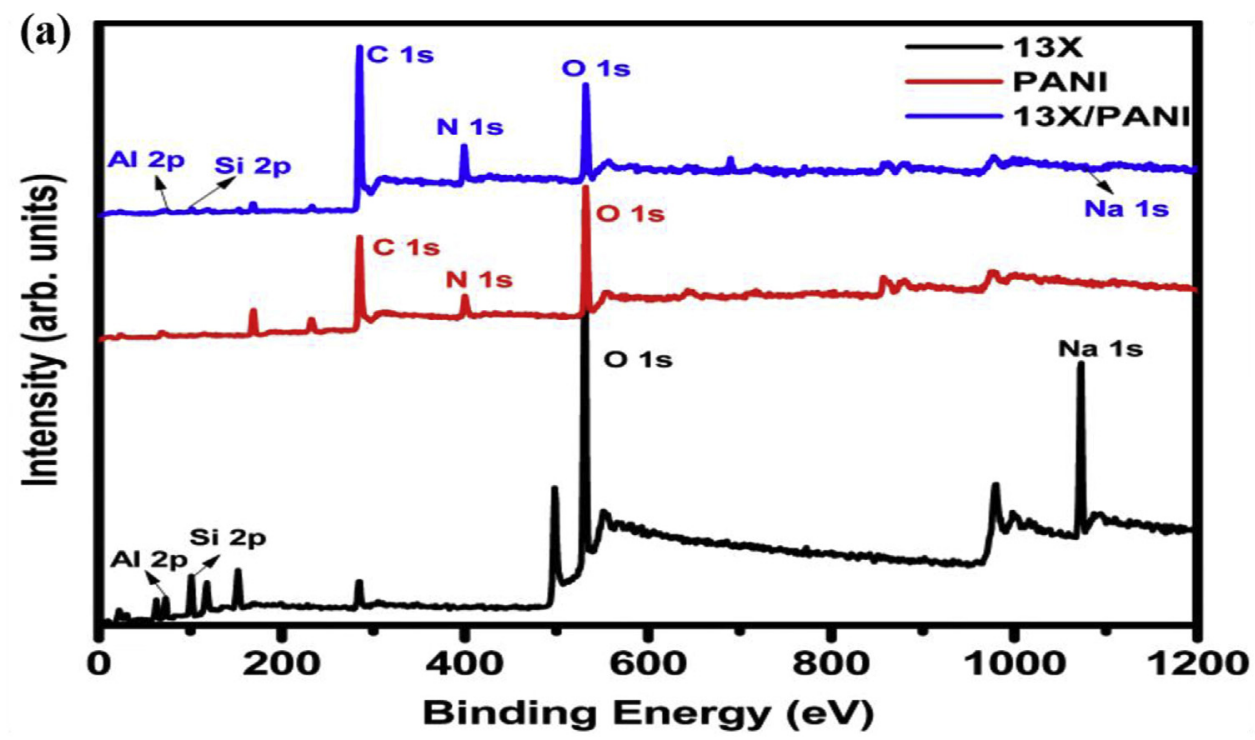

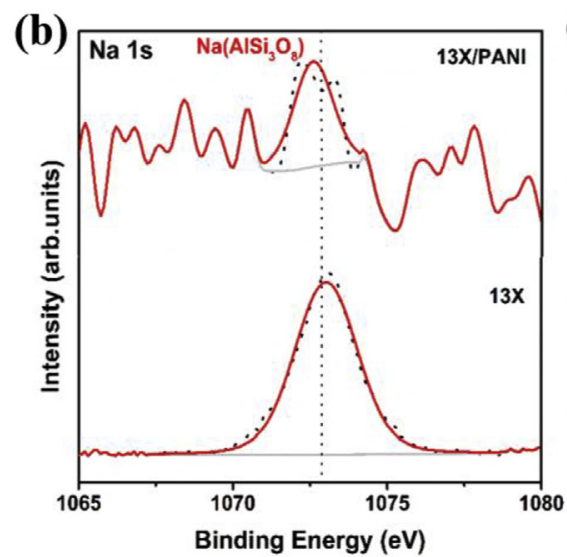

(e)

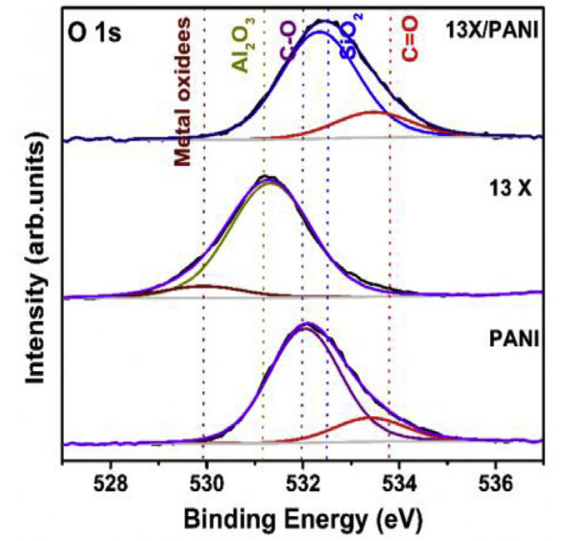

(c)

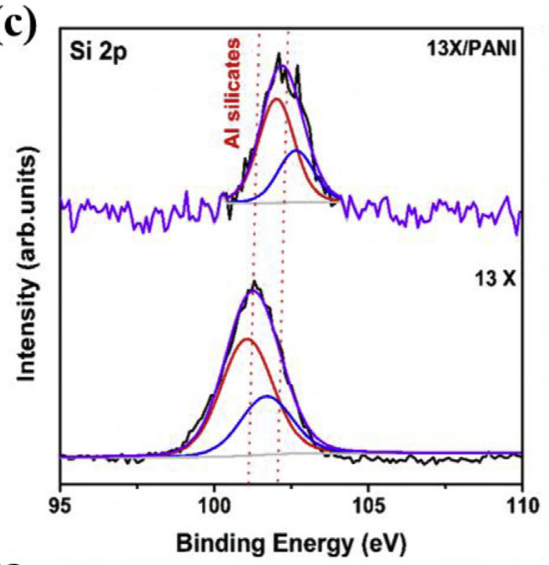

(f)

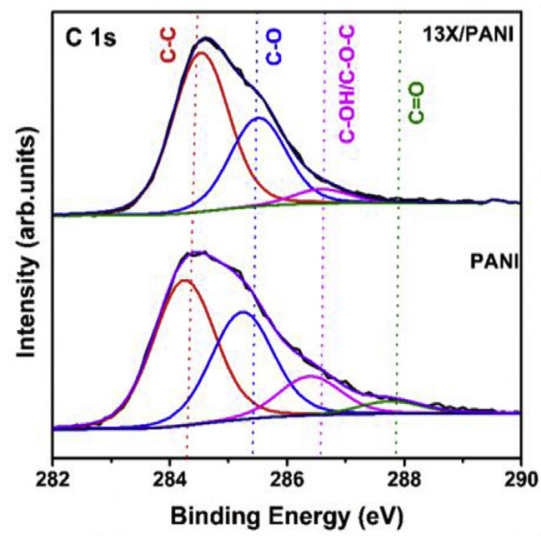

(d)

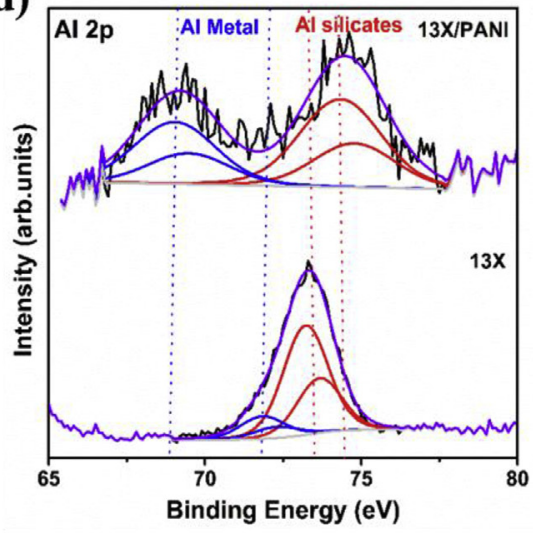

(g)

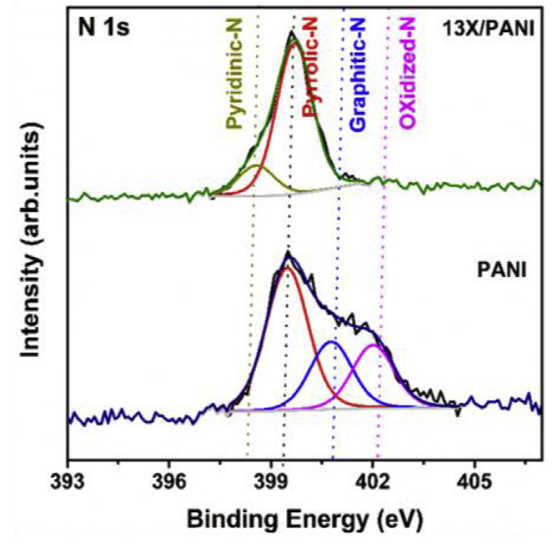

Fig. 6 - XPS survey and wide scan spectra of the synthesized materials.

HER and OER performances

Fig. 7 shows the OER and HER performance of the fabricated 13X/PANI electrodes with different cycle numbers 10, 15, 20 and 25. To find the best performance of the electrode material towards HER and OER, varying the cycle number study was conducted. The thickness of the electrode materials plays a crucial role in the electrochemical performances. If the 

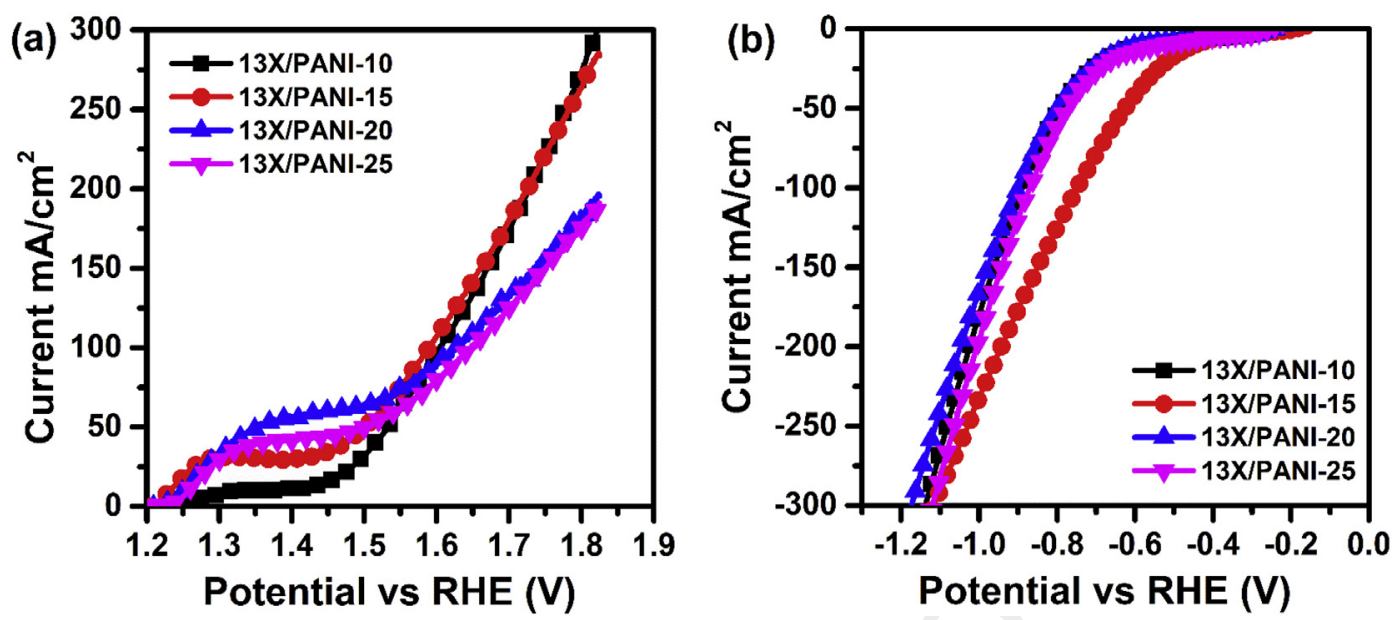

Fig. 7 - (a) OER and (b) HER performances of 13X/PANI composite with varying cycle number.

electrode possesses more thickness of high loading (more deposition) leads to the inferior performance of the electrode. Hence, the optimum loading was an important parameter to fix the electrode thickness of the present study. In this study, the composite electrode 13X/PANI-15 (Fig. 7(a)) shows good OER activity with a lower overpotential and higher current density compared to all the other composites. The plausible reason was at low cycle number (13X/PANI-10), the PANI could not fully cover the surface of the electrode. At higher cycle numbers 20 and 25 (13X/PANI-20 and 13X/PANI-25), the more deposition of PANI in the electrode surface. In both the cases, electrostatic interaction between the $13 \mathrm{X}$ zeolite and PANI was reduced and caused the poor performances towards OER. Similarly, the HER for 13X/PANI-15 (Fig. 7(b)) exhibited better performances than the remaining electrodes.

Fig. 8 shows the comparative OER and HER performance of the prepared 13X, PANI and 13X/PANI-15 composite electrodes in a three-electrode setup. Fig. 8(a) shows the HER LSV curves, the overpotential at a current density of $10 \mathrm{~mA} \mathrm{~cm}^{-2}$ were measured as $240 \mathrm{mV}, 906 \mathrm{mV}$ and $322 \mathrm{mV}$ for 13X, PANI and 13X/PANI-15 electrodes, respectively. OER LSV curves were given in Fig. 8(b), the overpotential measured at
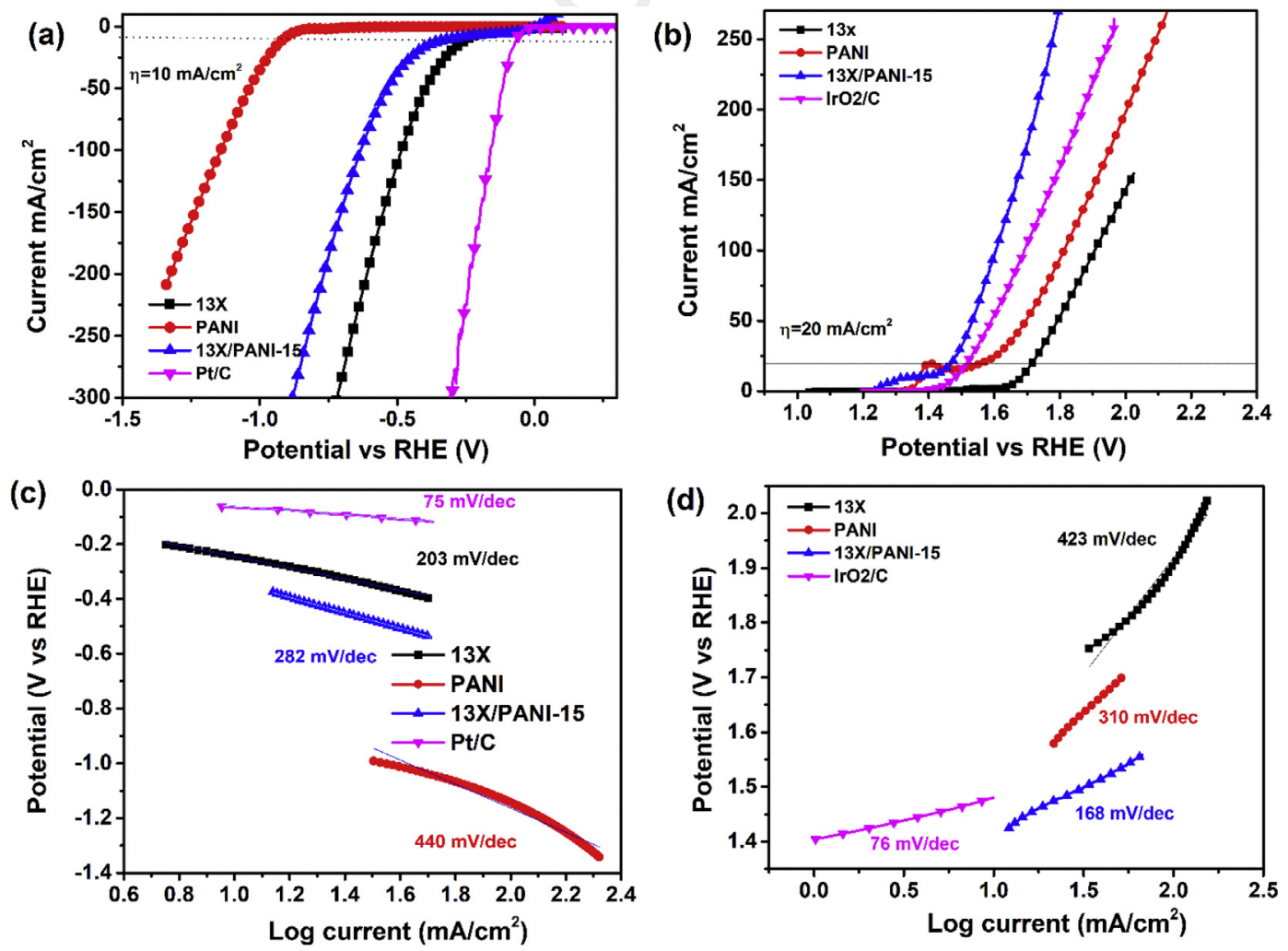

Fig. 8 - (a) and (c) represents the HER and its corresponding Tafel plots of the fabricated electrodes; (b) and (d) represents OER and its corresponding Tafel plots of the fabricated electrodes. 

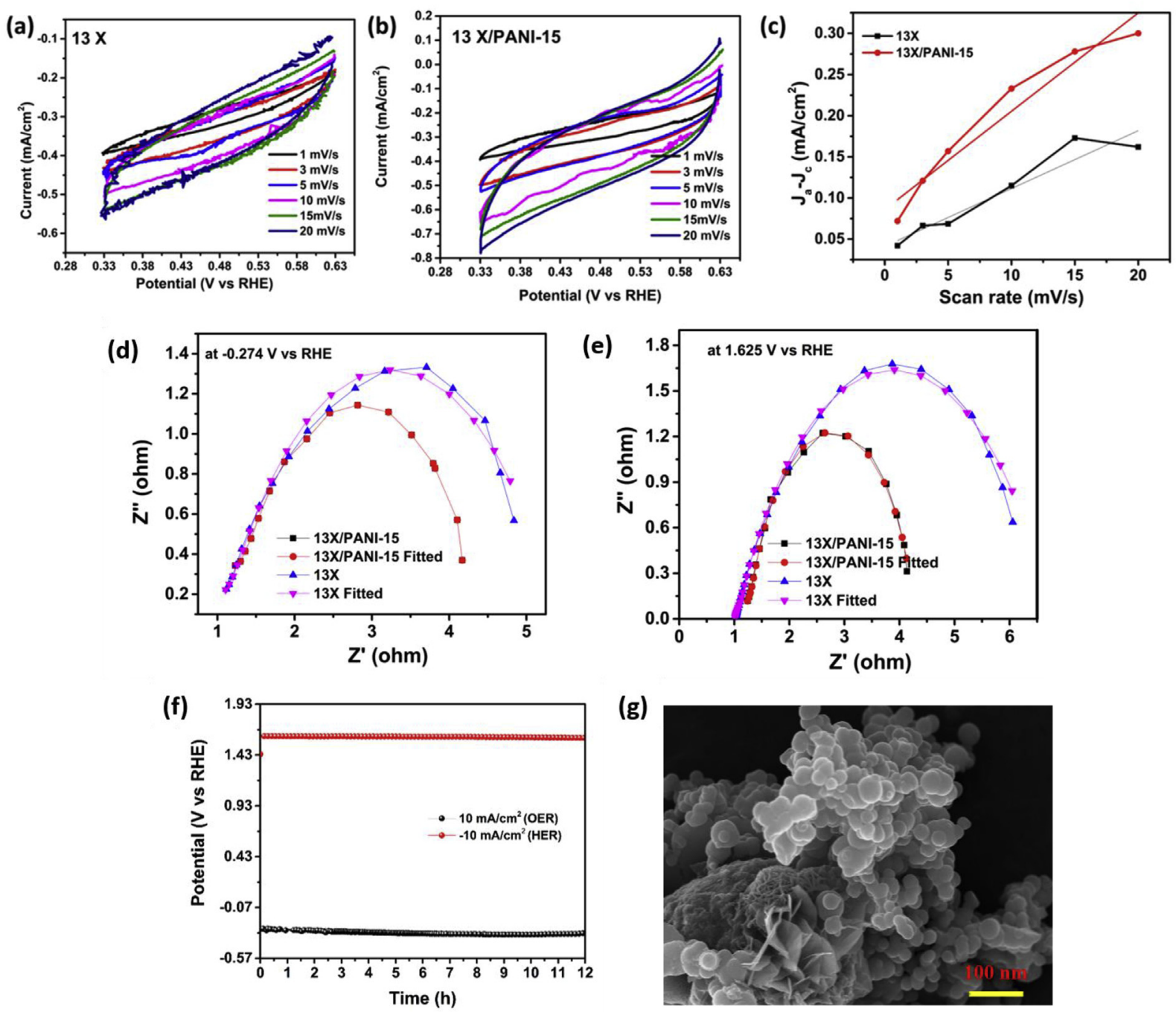

Fig. 9 - (a) and (b) represents the cyclic voltammograms of $13 \mathrm{X}$ and 13X/PANI-15, respectively with varying the scan rate from 1 to $20 \mathrm{mV} \mathrm{s}^{-1}$; (c) plot of anodic and cathodic non-faradaic regions versus the scan rate; (d) and (e) shows the Nyquist plots for HER (at $-0.274 \mathrm{~V}$ vs RHE) and OER (at $1.6254 \mathrm{~V}$ vs RHE); (f) Stability test conducted by chronopotentiometry technique for 13X/PANI-15 electrocatalyst; (g) SEM image of 13X/PANI-15 after the stability test.

$20 \mathrm{~mA} \mathrm{~cm}^{-2}$ current density was $230 \mathrm{mV}, 480 \mathrm{mV}$ and $322 \mathrm{mV}$. The Tafel plot was used to find a better understanding of the kinetics of electrochemical reactions for HER and OER [47]. The Tafel slope value gives crucial information on the ratedetermining step in an electrochemical reaction and also it is an intrinsic property of the electrode material. Tafel plots traced from the LSV curves of HER and OER were given in Fig. 8(c) and (d), respectively. The Tafel slopes of HER were $203 \mathrm{mV} \mathrm{dec}^{-1}, 440 \mathrm{mV} \mathrm{dec}{ }^{-1}$ and $282 \mathrm{mV} \mathrm{dec}^{-1}$ for 13X, PANI and 13X/PANI-15 electrodes, respectively. The OER Tafel slopes were $423 \mathrm{mV} \mathrm{dec}^{-1}, 310 \mathrm{mV} \mathrm{dec}^{-1}$ and $168 \mathrm{mV} \mathrm{dec}^{-1}$ for 13X, PANI and 13X/PANI-15, respectively. It is known that enhancing the electrochemical properties can be attained by varying the surface composition and microstructure $[48,49]$. The Tafel values of $13 \mathrm{X}$ and 13X/PANI-15 was not much difference in both the HER and OER studies, it clearly indicates the high surface area of the electrode, which may have contributed to HER and OER.

Another important auxiliary tool towards the search of potential catalysts for HER and OER is double-layer capacitance $\left(C_{\mathrm{dl}}\right)$, which is used to estimate the electrochemically active surface of the prepared catalyst. The electrochemically active surface area of the catalyst is proportional to the capacitance value of the catalyst. $C_{d l}$ can be calculated by the cyclic voltammetry method, using a non-faradaic current region of the CV runs recorded at different scan rates. The current density of anodic and cathodic non-faradaic regions (i.e. $\mathrm{J}_{\mathrm{a}}$ and $\mathrm{J}_{\mathrm{c}}$, respectively) were used to calculate $\Delta \mathrm{J}\left(=\mathrm{J}_{\mathrm{a}}-\mathrm{J}_{\mathrm{c}}\right)$, which is plotted against the scan rate. The slope of the linear graph between $\Delta \mathrm{J}$ versus scan rate will give the $C_{d l}$ value. A higher value of double-layer capacitance means the catalyst has higher electrochemical active surface area [50]. Fig. 9(a) and (b) 
shows the CV curves of $13 \mathrm{X}$ and 13X/PANI-15 at different scan rate. From the obtained results, we found that $13 \mathrm{X}$ possesses the $\mathrm{C}_{\mathrm{dl}}$ of $3.5 \mathrm{mF} \mathrm{cm}^{-2}$. Whereas 13X/PANI-15 composite exhibit $6 \mathrm{mF} \mathrm{cm}^{-2}$. It clearly illustrates 13X/PANI-15 shows superior $C_{d l}$ value and also have higher electrochemical active surface area.

For the further understanding of electrode kinetics of the prepared electrode materials, we performed potential applied electrochemical impedance spectroscopy (EIS). The Nyquist plots for HER (at -0.274 V vs RHE) and OER (at 1.6254 V vs RHE) given in Fig. $9(d)$ and (e), respectively. The series $\left(R_{s}\right)$ and charge transfer resistance $\left(\mathrm{R}_{\mathrm{ct}}\right)$ at $-0.274 \mathrm{~V}$ vs RHE for $13 \mathrm{X} /$ PANI-15 and $13 \mathrm{X}$ were $1.19 \Omega, 2.841 \Omega$ and $1.02 \Omega, 5.616 \Omega$, respectively. The series $\left(R_{s}\right)$ sand charge transfer resistance $\left(R_{c t}\right)$ at $1.6254 \mathrm{~V}$ vs RHE for $13 \mathrm{X} / \mathrm{PANI}-15$ and $13 \mathrm{X}$ were $0.694 \Omega$, $3.08 \Omega$ and $0.879 \Omega, 4.826 \Omega$, respectively.

We have evaluated the durability by conducting chronopotentiometry stability test at $10 \mathrm{~mA} \mathrm{~cm}^{-2}$ and $-10 \mathrm{~mA} \mathrm{~cm}^{-2}$ for OER and HER respectively (Fig. 9(f)). As we can see from the figure for both OER and HER 13X/PANI-15 electrocatalyst shows a very good stable nature even after $12 \mathrm{~h}$ of stability test. After the stability test, the electrode (13X/PANI-15) was subjected into SEM analysis. The electrode almost retains their initial morphology after $12 \mathrm{~h}$ of stability test (Inset of Fig. 9(f)). These results clearly demonstrate the stability of the prepared electrode material and it could be a potential candidate of HER and OER applications.

\section{Conclusions}

In summary, the HER and OER electrocatalyst of 13X/PANI composite were synthesized by a novel and facile route. XRD and FT-IR confirm the successful synthesis of $13 \mathrm{X}$ zeolite material by the hydrothermal method. The surface area of the 13X was found to be $625 \mathrm{~m}^{2} \mathrm{~g}^{-1}$. In 13X/PANI composite, XRD showed some mixed amorphous and crystalline structure of PANI with no obvious change in the structure of the 13X/PANI composite. FE-SEM morphologies showed successful incorporation of $13 \mathrm{X}$ into the polymer backbone with some wrapping by PANI. From the LSV curves, the optimum electrocatalyst was found to be 13X/PANI-15 when compared with other composite electrodes. The prepared 13X/PANI-15 composite electrode was evaluated using LSV and Tafel plots illustrating that the prepared composite electrode has a greater potential to be used in HER and OER applications. 13X zeolite/PANI-15 electrode show excellent catalytic performance about the overpotential at $10 \mathrm{~mA} \mathrm{~cm}^{-2}$ for HER and the overpotential at $20 \mathrm{~mA} \mathrm{~cm}{ }^{-2}$ for OER. The present work demonstrated that the $13 \mathrm{X} / \mathrm{PANI}$ composite is not only robust and stable but also inexpensive HER and OER electrocatalyst.

\section{Acknowledgement}

The authors gratefully acknowledge the financial support from BK 21 PLUS, Creative Human Resource Development Program for IT Convergence, Pusan National University, Busan, South Korea. This study was financially supported by the 2020-2021 Post-Doc. Development Program of Pusan
National University. The author thanks to Researchers Supporting Project Number (RSP-2019/6), King Saud University, Q3 Riyadh, Saudi Arabia.

\section{Declaration of competing interest}

The authors declare that they have no known competing financial interests or personal relationships that could have appeared to influence the work reported in this paper.

\section{Appendix A. Supplementary data}

Supplementary data to this article can be found online at https://doi.org/10.1016/j.ijhydene.2020.07.194.

\section{R E F E R E N C E S}

[1] Bard AJ, Fox MA. Artificial Photosynthesis: solar splitting of water to hydrogen and oxygen. Acc Chem Res 1995;28:141-5. https://doi.org/10.1021/ar00051a007.

[2] Chow J, Kopp RJ, Portney PR. Energy resources and global development. Science 2003;302:1528-31. https://doi: 10.1126/ science.1091939.

[3] Bockris JO. A hydrogen economy. Science 1972;176:1323. https://doi: 10.1126/science.176.4041.1323.

[4] Turner JA. Sustainable hydrogen production. Science 2004;305:972-4. https://doi: 10.1126/science.1103197.

[5] Schlapbach L, Zuttel A. Hydrogen-storage materials for mobile applications. Nature 2001;414:353-8. https://doi.org/ 10.1038/35104634.

[6] Wang J, Cui W, Liu Q, Xing Z, Asiri AM, Sun X. Recent progress in cobalt-based heterogeneous catalysts for electrochemical water splitting. Adv Mater 2016;28:215-30. https://doi: 10.1002/adma.201502696.

[7] Suntivich J, May KJ, Gasteiger HA, Goodenough JB, ShaoHorn Y. A perovskite oxide optimized for oxygen evolution catalysis from molecular orbital principles. Science 2011;334:1383-5. https://doi: 10.1126/science.1212858.

[8] Kanan MW, Nocera DG. In situ formation of an oxygenevolving catalyst in neutral water containing phosphate and $\mathrm{CO}^{2+}$. Science 2008;321:1072-5. https://doi: 10.1126/science. 1162018.

[9] Liu Q, Xie L, Qu F, Liu Z, Du G, Asiri AM, Sun XA. A porous $\mathrm{Ni}_{3} \mathrm{~N}$ nanosheet array as a high-performance non-noblemetal catalyst for urea-assisted electrochemical hydrogen production. Inorg Chem Front 2017;4:1120-4. https://doi.org/ 10.1039/C7QI00185A.

[10] Xie M, Xiong X, Yang L, Shi X, Asiri AM, Sun X. An Fe(TCNQ) nanowire array on Fe foil: an efficient non-noble-metal catalyst for the oxygen evolution reaction in alkaline media. Chem Commun 2018;54:2300-3. https://doi.org/10.1039/ C7CC09105B.

[11] Liu Q, Xie L, Liu Z, Du G, Asiri AM, Sun X. A Zn-doped $\mathrm{Ni}_{3} \mathrm{~S}_{2}$ nanosheet array as a high-performance electrochemical water oxidation catalyst in alkaline solution. Chem Commun 2017;53:12446-9. https://doi.org/10.1039/C7CC06668F.

[12] Dionigi F, Strasser P. NiFe-based (Oxy)hydroxide catalysts for oxygen evolution reaction in non-acidic electrolytes. Adv Energy Mater 2016;6:1600621. https://doi.org/10.1002/ aenm.201600621.

[13] Feng YY, Zhang HJ, Fang L, Mu YP, Wang Y. Uniquely monodispersing nife alloyed nanoparticles in three- 
dimensional strongly linked sandwiched graphitized carbon sheets for high-efficiency oxygen evolution reaction. ACS Catal 2016;6:4477-85. https://doi.org/10.1021/ acscatal.6b00481.

[14] Pi YC, Zhang N, Guo SJ, Guo J, Huang XQ. Ultrathin laminar ir superstructure as highly efficient oxygen evolution electrocatalyst in broad pH range. Nano Lett 2016;16:4424-30. https://doi.org/10.1021/acs.nanolett.6b01554.

[15] Friend RH, Gymer RW, Holmes AB, Burroughes JH, Marks RN, Taliani $\mathrm{C}$, et al. Electroluminescence in conjugated polymers. Nature 1999;397:121-8. https://doi.org/10.1038/16393.

[16] Muller CD, Falcou A, Reckefuss N, Rojahn M, Wiederhirn V, Rudati $\mathrm{P}$, et al. Multi-colour organic light-emitting displays by solution processing. Nature 2003;421:829-33. https:// doi.org/10.1038/nature01390.

[17] Sirringhuas H, Tessler N, Friend RH. Integrated optoelectronic devices based on conjugated polymers. Science 1988;280:1741-4. https://doi:10.1126/science.280. 5370.1741.

[18] Dimitrakopoulos CD, Mascaro DJ. Organic thin-film transistors: a review of recent advances. IBM J Res De 2001;45:11-27. https://doi: 10.1147/rd.451.0011.

[19] Yu G, Gao J, Hummelen JC, Wudl F, Heeger AJ. Polymer photovoltaic cells: enhanced efficiencies via a network of internal donor-acceptor heterojunctions. Science 1995;270:1789-91. https://doi: 10.1126/science.270.5243.1789.

[20] Brabec CJ, Sariciftci NS, Hummelen JC. Plastic solar cells. Adv Funct Mater 2001;11:15-26. https://doi.org/10.1002/16163028(200102)11:1<15::AID-ADFM15>3.0.CO;2-A.

[21] Malkaj P, Dalas E, Viteratos E, Sakkopoulos S. pH electrodes constructed from polyaniline/zeolite and polypyrrole/zeolite conductive blends. J Appl Polym Sci 2006;101:1853-6. https:// doi.org/10.1002/app.23590.

[22] Luo YC, Do JS. Amperometric ammonium ion sensor based on polyaniline-poly(styrene sulfonate-co-maleic acid) composite conducting polymeric electrode. Sens Actuators, B 2006;115:102-8. https://doi.org/10.1016/j.snb.2005.08.027.

[23] MacDiarmid AG, Mu SL, Somasiri NLD, Wu W. Polyaniline: interconversion of metallic and insulating forms. Mol Cryst Liq Cryst 1985;121:173-80. https://doi.org/10.1080/ 00268948508074857.

[24] Koboyashi T, Yoneyama H, Tamura H. Electrochemical reactions concerned with electrochromism of polyaniline film-coated electrodes. J Electroanal Chem 1984;177:281-91. https://doi.org/10.1016/0022-0728(84)80229-6.

[25] Sazou D, Kosseoglou D. Corrosion inhibition by Nafion ${ }^{\circledR}-$ polyaniline composite films deposited on stainless steel in a two-step process. Electrochim Acta 2006;51:2503-11. https:// doi.org/10.1016/j.electacta.2005.07.033.

[26] Habibi B, Pournaghi-Azar MH, Abdolmohammad-Zadeh $\mathrm{H}$, Razmi H. Electrocatalytic oxidation of methanol on mono and bimetallic composite films: $\mathrm{Pt}$ and $\mathrm{Pt}-\mathrm{M}(\mathrm{M}=\mathrm{Ru}$, Ir and $\mathrm{Sn})$ nano-particles in poly(o-aminophenol). Int J Hydrogen Energy 2009;34:2880-92. https://doi.org/10.1016/ j.ijhydene.2009.01.072.

[27] Tintula KK, Pitchumani S, Sridhar P, Shukla AK. A solidpolymer-electrolyte direct methanol fuel cell (DMFC) with Pt$\mathrm{Ru}$ nanoparticles supported onto poly(3,4ethylenedioxythiophene) and polystyrene sulphonic acid polymer composite as anode. J Chem Sci 2010;122:381-9. https://doi.org/10.1007/s12039-010-0043-6.

[28] Yano J, Shiraga T, Kitani A. Electrocatalytic activity of metalpolyaniline film electrodes for direct methanol fuel cell. J New Mater Electrochem Syst 2008;11:235-41. https://doi: 10. 1016/S0379-6779(00)01522-8.

[29] Vinodh R, Rana PJS, Gopi CVVM, Yang Y, Atchudan R, Venkatachalam K, et al. Polyaniline-13X zeolite compositesupported platinum electrocatalysts for direct methanol fuel cell applications. Polym Int 2019;68:929-35. https://doi.org/ 10.1002/pi.5783.

[30] Jung HC, Vinodh R, Gopi CVVM, Yi M, Kim HJ. Novel composite electrode material derived from hypercrosslinked polymer of pyrene and polyaniline for symmetric supercapacitor. Mater Lett 2019;257:126732. https://doi.org/ 10.1016/j.matlet.2019.126732.

[31] Wang L, Lu X, Lei S, Song Y. Graphene-based polyaniline nanocomposites: preparation, properties and applications. J Mater Chem 2014;2:4491-509. https://doi.org/10.1039/ C3TA13462H.

[32] Wei ZJ, Wang CY, Liu H, Zou SW, Tong Z. Halloysite nanotubes as particulate emulsifier: preparation of biocompatible drug-carrying PLGA microspheres based on Pickering emulsion. J Appl Polym Sci 2012;125:E358-68. https://doi.org/10.1002/app.36456.

[33] Liu YS, Nan HM, Cai Q Li HD. Fabrication of halloysite@polypyrrole composite particles and polypyrrole nanotubes on halloysite templates. J Appl Polym Sci 2012;125:E638-43. https://doi.org/10.1002/app.34125.

[34] de Lucas A, Uguina MA, Covian I, Rodriguez L. Synthesis of 13X zeolite from calcined kaolins and sodium silicate for use in detergents. Ind Eng Chem Res 1992;31:2134-40. https:// doi.org/10.1021/ie00009a010.

[35] Joshi MS, Joshi VV, Choudhari AL, Kasture MW. Structural studies of natural heulandite using infrared spectroscopy. Mater Chem Phys 1997;48:160-3. https://doi.org/10.1016/ S0254-0584(97)80112-5.

[36] Terzano R, Spagnuolo M, Medici L, Tateo F. Spectroscopic investigation on the chemical forms of $\mathrm{Cu}$ during the synthesis of zeolite $\mathrm{X}$ at low temperature. Appl Geochem 2006;21:993-1005. http://hdl.handle.net/1854/LU-386405.

[37] Sponer JE, Sobalik Z. Effect of metal coordination on the charge distribution over the cation binding sites of zeolites: a combined experimental and theoretical study. J Phys Chem 2001;B105:8285-90. https://doi.org/10.1021/jp010098j.

[38] Lechert H, Kacirek H. Investigations on the crystallization of X-type zeolites. Zeolites 1991;11:720-8. https://doi.org/ 10.1016/S0144-2449(05)80178-2.

[39] Chunyu Z, Aref A, Chunjie Y, Xiumei Q, Hongquan W, Yunan M. Characteristics and evaluation of synthetic 13X zeolite from Yunnan's natural halloysite. J Porous Mater 2013;20:587-94. https://doi.org/10.1007/s10934-012-9631-9.

[40] Buron C, Lakard B, Monnin A, Moutarlier V, Lakard S. Elaboration and characterization of polyaniline films electrodeposited on tin oxides. Synth Met 2011;161:2162-9. https://doi.org/10.1016/j.synthmet.2011.08.021.

[41] Wei H, Gu H, Guo J, Wei S, Guo Z. Electropolymerized polyaniline nanocomposites from multi-walled carbon nanotubes with tuned surface functionalities for electrochemical energy storage. J Electrochem Soc 2013;160:G3038-45. https://doi: 10.1149/2.006307jes.

[42] Armes SP, Gottesfeld S, Berry JG, Garzon F, Agnew SF. Conducting polymer-colloidal silica composites. Polymer 1991;32:2325-30. https://doi.org/10.1016/0032-3861(91)90068-T.

[43] Maeda S, Gill M, Armes SP, Fletcher IW. Surface characterization of conducting polymer-silica nanocomposites by x-ray photoelectron spectroscopy. Langmuir 1995;11:1899-904. https://doi.org/10.1021/la00006a014.

[44] Ballav N, Biswas M. A conductive composite of polythiophene with 13X-zeolite. Mater Sci Eng B 2006;129:270-2. https://doi.org/10.1016/j.mseb.2005.12.024.

[45] Chul HD, Vinodh R, Gopi CVVM, Deviprasath C, Kim HJ, Yi M. Effect of the cobalt and zinc ratio on the preparation of zeolitic imidazole frameworks (ZIFs): synthesis, characterization and supercapacitor applications. Dalton Trans 2019;48:14808-19. https://doi.org/10.1039/ C9DT03306H. 
[46] Mahat MM, Mawad D, Nelson GW, Fearn S, Palgrave RG, Payne DJ, et al. Elucidating the deprotonation of polyaniline films by X-ray photoelectron spectroscopy. J Mater Chem.C 2015;3:7180-6. https://doi.org/10.1039/C5TC01038A.

[47] Chen J, Xia G, Jiang P, Yang Y, Li R, Shi R, eta l. Active and durable hydrogen evolution reaction catalyst derived from pd-doped metal-organic frameworks. ACS Appl Mater Interfaces 2016;8:13378-83. https://doi.org/10.1021/ acsami.6b01266.

[48] Dalla Corte DA, Torres C, Correa PS, Rieder ES, Malfatti CF. The hydrogen evolution reaction on nickel-polyaniline composite electrodes. Int J Hydrogen Energy 2012;37:3025-32. https://doi.org/10.1016/ j.ijhydene.2011.11.037.

[49] Murat F, Esra T, Yuce AO, Kardas G. The noble metal loading binary ironezinc electrode for hydrogen production. Int J Hydrogen Energy 2017;42:6455-61. https://doi.org/10.1016/ j.ijhydene.2016.11.078.

[50] Łukaszewski M, Soszko M, Czerwiński A. Electrochemical methods of real surface area determination of noble metal electrodes - an overview. Int J Electrochem Sci 2016;11:4442-69. https://doi: 10.20964/2016.06.71. 